\section{AB003. Increased CD69+ tissue-resident memory T cells and STAT3 expression in cutaneous lupus erythematosus patients recalcitrant to antimalarials}

\author{
Majid Zeidi ${ }^{1,2}$, Kristen L. Chen ${ }^{1,2}$, Krisha Desai ${ }^{1,2}$, \\ Hee Joo Kim ${ }^{1,2,3}$, Srita Chakka ${ }^{2}$, Rachel Lim ${ }^{1}$, \\ Victoria P. Werth ${ }^{1,2}$ \\ ${ }^{1}$ Corporal Michael J. Crescenz VAMC, Philadelphia, PA, USA; \\ ${ }^{2}$ Department of Dermatology, University of Pennsylvania, Philadelphia, \\ PA, USA; ${ }^{3}$ Department of Dermatology, Gil Medical Center, Gachon \\ University College of Medicine, Incheon, Korea \\ Correspondence to: Victoria P. Werth. Department of Dermatology, \\ Perelman Center for Advanced Medicine, Suite 1-330A, 3400 Civic \\ Center Boulevard, Philadelphia, PA 19104, USA. \\ Email: werth@pennmedicine.upenn.edu.
}

Background: Cutaneous lupus erythematosus (CLE) is an autoimmune disease involving $\mathrm{T}$ lymphocytes, plasmacytoid dendritic cells ( $\mathrm{pDCs}$ ), and myeloid dendritic cells (mDCs). While oral antimalarials, including hydroxychloroquine (HCQ) and quinacrine (QC) are first-line systemic therapy for all CLE subtypes, some patients remain refractory to both HCQ and HCQ + QC. To better understand reasons for refractoriness in CLE, we investigated the immunologic characteristics of patients who responded to antimalarials versus those who did not.

Methods: Biopsies from 65 CLE patients with well characterized treatment response to HCQ $(n=22)$ and HCQ + QC ( $n=24)$, as well as treatment failure to HCQ + QC $(n=19)$ were studied via immunohistochemistry and polymerase chain reaction. Lesional skin was biopsied prior to antimalarial treatment. The patient's CLASI score-a measure of disease activity—at the time of the biopsy was also determined.

Results: Immunohistochemistry showed CD69+ tissueresident memory $\mathrm{T}\left(\mathrm{T}_{\mathrm{RM}}\right)$ cells were significantly higher in HCQ + QC-nonresponders compared to HCQ- and HCQ + QC-responders. mDCs were significantly higher in HCQ +QC-responders compared to HCQ-responders and HCQ $+\mathrm{QC}$-nonresponders. There were significantly higher $\mathrm{pDCs}$ in the HCQ-responders compared to the nonresponders. CLASI scores of HCQ + QC-nonresponders correlated positively with the number of $\mathrm{T}_{\mathrm{RM}}$ cells $(\mathrm{r}=0.6254, \mathrm{P}=0.017)$ and macrophages $(\mathrm{r}=0.5726, \mathrm{P}=0.041)$. mRNA expression demonstrated high STAT3 expression in HCQ + QCnonresponders.

Conclusions: An increased number of CD69+ $T_{R M}$ cells and correlation between CD69+ $\mathrm{T}_{\mathrm{RM}}$ cells and macrophages with CLASI scores in the HCQ + QC-nonresponders, a finding not seen in either HCQ or HCQ + QC-responders, may suggest $\mathrm{CD} 69+\mathrm{T}_{\mathrm{RM}}$ cells and macrophages are involved in antimalarial-refractory skin disease.

Keywords: Cutaneous lupus erythematosus (CLE); antimalarials; tissue-resident memory T cell; myeloid dendritic cell (mDC)

doi: 10.21037/atm.2021.AB003

Open Access Statement: This is an Open Access article distributed in accordance with the Creative Commons Attribution-NonCommercial-NoDerivs 4.0 International License (CC BY-NC-ND 4.0), which permits the noncommercial replication and distribution of the article with the strict proviso that no changes or edits are made and the original work is properly cited (including links to both the formal publication through the relevant DOI and the license). See: https://creativecommons.org/licenses/by-nc-nd/4.0/.

Cite this abstract as: Zeidi M, Chen KL, Desai K, Kim HJ, Chakka S, Lim R, Werth VP. Increased CD69+ tissue-resident memory $\mathrm{T}$ cells and STAT3 expression in cutaneous lupus erythematosus patients recalcitrant to antimalarials. Ann Transl Med 2021;9(5):AB003. doi: 10.21037/atm.2021.AB003 